\title{
Biogas upgrading and biochemical production from gas fermentation: impact of microbial community and gas composition
}

Omar, Basma; El-Gammal, Maie; Abou-Shanab, Reda; Fotidis, Ioannis; Angelidaki, Irini; Zhang, Yifeng

Published in:

Bioresource Technology

Link to article, DOI:

10.1016/j.biortech.2019.121413

Publication date:

2019

Document Version

Peer reviewed version

Link back to DTU Orbit

Citation (APA):

Omar, B., El-Gammal, M., Abou-Shanab, R., Fotidis, I., Angelidaki, I., \& Zhang, Y. (2019). Biogas upgrading and biochemical production from gas fermentation: impact of microbial community and gas composition. Bioresource Technology, 286, [121413]. https://doi.org/10.1016/j.biortech.2019.121413

\section{General rights}

Copyright and moral rights for the publications made accessible in the public portal are retained by the authors and/or other copyright owners and it is a condition of accessing publications that users recognise and abide by the legal requirements associated with these rights.

- Users may download and print one copy of any publication from the public portal for the purpose of private study or research.

- You may not further distribute the material or use it for any profit-making activity or commercial gain

- You may freely distribute the URL identifying the publication in the public portal 


\section{Accepted Manuscript}

Biogas upgrading and biochemical production from gas fermentation: impact of microbial community and gas composition

Basma Omar, Maie El-Gammal, Reda Abou-Shanab, Ioannis A. Fotidis, Irini Angelidaki, Yifeng Zhang

PII: S0960-8524(19)30643-1

DOI: https://doi.org/10.1016/j.biortech.2019.121413

Article Number: 121413

Reference: $\quad$ BITE 121413

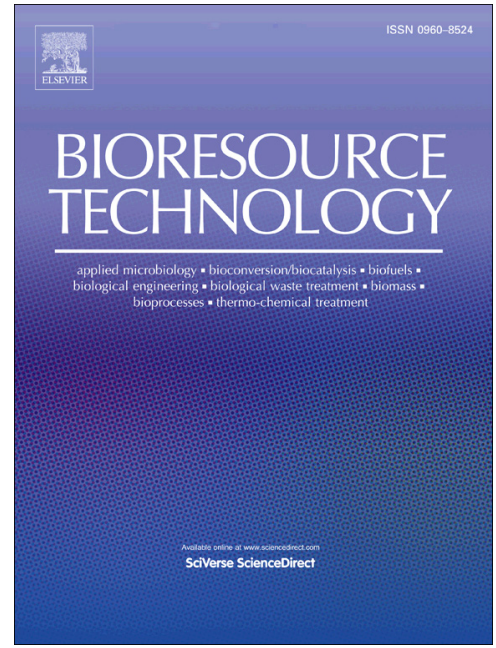

To appear in:

Bioresource Technology

Received Date: $\quad 21$ March 2019

Revised Date: $\quad 1$ May 2019

Accepted Date: $\quad 2$ May 2019

Please cite this article as: Omar, B., El-Gammal, M., Abou-Shanab, R., Fotidis, I.A., Angelidaki, I., Zhang, Y., Biogas upgrading and biochemical production from gas fermentation: impact of microbial community and gas composition, Bioresource Technology (2019), doi: https://doi.org/10.1016/j.biortech.2019.121413

This is a PDF file of an unedited manuscript that has been accepted for publication. As a service to our customers we are providing this early version of the manuscript. The manuscript will undergo copyediting, typesetting, and review of the resulting proof before it is published in its final form. Please note that during the production process errors may be discovered which could affect the content, and all legal disclaimers that apply to the journal pertain. 


\section{Biogas upgrading and biochemical production from gas fermentation: impact of microbial community and gas composition}

Basma Omar $^{\text {a, b }}$, Maie El-Gammal ${ }^{\mathrm{b}}$, Reda Abou-Shanab ${ }^{\mathrm{c}}$, Ioannis A. Fotidis a , Irini Angelidaki ${ }^{\text {a }}$, Yifeng Zhang ${ }^{\text {a, * }}$

${ }^{a}$ Department of Environmental Engineering, Technical University of Denmark, Bygningstorvet Bygning 115, DK-2800 Kgs. Lyngby, DK

${ }^{\mathrm{b}}$ Department of Environmental Sciences, Faculty of Science, Damietta University, 34517 Damietta, Egypt

${ }^{c}$ Department of Environmental Biotechnology, City of Scientific Research and Technology Applications, Alexandria, 21934, Egypt

*Corresponding Author: Department of Environmental Engineering, Technical University of Denmark, Bygningstorvet Bygning 115, 2800 Kgs. Lyngby, DK, Phone: (+45) 45251410; Fax:(+45) 45933850; e-mail: yifz@env.dtu.dk 


\begin{abstract}
The present study proposes a novel alternative method of the current biogas upgrading techniques by converting $\mathrm{CO}_{2}$ (in the biogas) into valuable chemicals (e.g., volatile fatty acids) using $\mathrm{H}_{2}$ as energy source and acetogenic mixed culture as biocatalyst. The influence of thermal treatment $\left(90^{\circ} \mathrm{C}\right)$ on the inhibition of the methanogenic archaea and enriching the acetogenic bacteria in different inocula (mesophilic and thermophilic) was initially tested. The most efficient inoculum that achieved the highest performance through the fermentation process was further used to define the optimum $\mathrm{H}_{2} / \mathrm{CO}_{2}$ gas ratio that secures maximum production yield of chemicals and maximum biogas upgrading efficiency. In addition, $16 \mathrm{~S}$ rRNA analysis of the microbial community was conducted at the end of the experimental period to target functional microbes. The maximum biogas content $(77 \%(\mathrm{v} / \mathrm{v}))$ and acetate yield $(72 \%)$ were achieved for $2 \mathrm{H}_{2}: 1 \mathrm{CO}_{2}$ ratio (v/v), with Moorella sp. 4 as the most dominant thermophilic acetogenic bacterium.
\end{abstract}

Keywords: Biogas upgrading; Gas fermentation; Microbial community; Acetogens; AcetylCoA pathway 


\section{Introduction}

The growing concern about climate change, fossil fuels depletion and environmental impacts of current energy sources has together stimulated the search for sustainable, renewable and environment-friendly energy sources. Biogas is attracting significant attention as a clean and $\mathrm{CO}_{2}$-neutral energy carrier (Awe et al., 2017). Biogas is generally composed of carbon dioxide (25-60\%) and methane (40-75\%) with several minor compounds depending on the organic source (Rotunno et al., 2017). The relatively high concentration of $\mathrm{CO}_{2}$ in raw biogas significantly reduces its calorific value. Biogas (e.g., $60 \% \mathrm{CH}_{4}$ and $40 \% \mathrm{CO}_{2}$, v/v) has a low heat value (LHV) of $17.7 \mathrm{MJ} / \mathrm{kg}$, while a $100 \% \mathrm{CH}_{4}$ gas has a $\mathrm{LHV}$ of $50.2 \mathrm{MJ} / \mathrm{kg}$ (Abdeen et al., 2016). Moreover, $\mathrm{CO}_{2}$ in biogas can increase carbon monoxide and hydrocarbon emissions during combustion and the corrosion in pipelines during transportation (Toledo-Cervantes et al., 2016). Therefore, the common application of biogas is restricted for heating and electricity production (Leonzio, 2016).

Biogas upgrading is one of the most efficient technologies that receives great interest in bioenergy industry (Kokkoli et al., 2018). It aims to concentrate the methane in biogas by removal or transformation of $\mathrm{CO}_{2}$ and other impurities (Kougias et al., 2017). The upgraded biogas with more than $95 \% \mathrm{CH}_{4}$ content is known as biomethane and can be injected directly into the existing natural gas grid or used as vehicle fuel (Micale, 2015). Several commercial technologies are currently used for biogas upgrading which are mainly based on physicochemical $\mathrm{CO}_{2}$ removal (Bassani et al., 2016). The high cost and the methane loss during separation of $\mathrm{CO}_{2}$ from biogas make these technologies economically and environmentally unfavourable (Angelidaki et al., 2018).

Alternatively, biogas can be upgraded through the biological conversion of $\mathrm{CO}_{2}$ (in biogas) to valuable liquid products such as alcohols and volatile fatty acids using $\mathrm{H}_{2}$ as an 
energy source (Angelidaki et al., 2018). Acetate, butyrate and the other produced fatty acids are important precursor for high value biofuels (Liew et al., 2016). Various microorganisms are capable of converting $\mathrm{CO}_{2}$ and $\mathrm{H}_{2}$ to liquid products (Schiel-Bengelsdorf and Dürre, 2012). Most of these microorganisms are acetogens, which efficiently ferment $\mathrm{C} 1$ compounds (including $\mathrm{CO}_{2}$ ) using $\mathrm{H}_{2}$ as an electron donor and produce valuable biofuels and chemicals (Fernández-naveira et al., 2017). However, various gas fermentation studies have been performed using pure culture, which faces several limitations. Low adaptation capacity to various substrates (e.g. toxic components) and high operation cost to sustain sterilization conditions make it less suitable for applying to large industrial systems (Fernández-naveira et al., 2017). On the other hand, mixed culture can be more suitable for applying to large industrial systems (Redl et al., 2017).

In practice, Hydrogen required for the fermentation process could be generated from large point sources such as soda manufacture, petroleum refinery, petrochemical plants and coal gasification (Luo and Angelidaki, 2012). The concept of renewable electricity utilization for $\mathrm{H}_{2}$ production has attracted great attention in recent years (Angelidaki et al., 2018). This sustainable technology which also known as power to gas (P2G) technology relies on water electrolysis using excess electricity generated by renewable energy sources (RES) such as wind mills and solar panels. Utilisation of $\mathrm{H}_{2}$ as a renewable energy carrier faces various challenges that are related to its very low volumetric energy density that requires infrastructure with high storage volume and high transportation cost (Kougias et al., 2017). In contrary, $\mathrm{H}_{2}$ generated from $\mathrm{P} 2 \mathrm{G}$ technology can be used as energy source to separate $\mathrm{CO}_{2}$ from biogas mixture and convert it to valuable biochemical (e.g., volatile fatty acids) using acetogenic bacteria. This new method is very promising as it integrates wind or solar energy technology with biochemical and biogas upgrading process. 
Biogas upgrading and biosynthesis of volatile fatty acids through mixed culture fermentation of $\mathrm{CO}_{2}$ and $\mathrm{H}_{2}$ were reported in our previous study (Omar et al., 2018). In that study, $\mathrm{CO}_{2}$ and $\mathrm{H}_{2}$ were successfully converted into volatile fatty acids (mainly acetate) using chemically treated mesophilic mixed culture. While, the methane content of the biogas was significantly increased. As this research area is still at its infancy, so more development with respect to microorganisms and conditions are necessary.

Therefore, the present study proposes a novel biogas upgrading method by fermenting $\mathrm{CO}_{2}$ (in the biogas) into chemicals using different mixed culture acetogenic consortia as biocatalyst and externally added $\mathrm{H}_{2}$ as energy source under different temperature. To achieve the main aim of the current study, a preliminary batch experiment was performed to select the most suitable microbial source of acetogens. Subsequently the most efficient inoculum through fermentation process was used to define the optimum $\mathrm{H}_{2} / \mathrm{CO}_{2}$ gas ratio that secures maximum biogas upgrading efficiency and maximum production yield of chemicals. The characterization of the microbial community was also conducted during the upgrading process.

\section{Materials and methods}

\subsection{Inocula and medium}

Mesophilic $\left(37 \pm 1^{\circ} \mathrm{C}\right)$ and thermophilic $\left(55 \pm 1^{\circ} \mathrm{C}\right)$ digested effluent derived from Danish full-scale biogas plants (Hashøj and Snertinge, respectively) were used as inocula in this study. Both plants are fed with pig and cow manure (70 to $90 \% \mathrm{w} / \mathrm{w})$ and organic waste (10 to $30 \% \mathrm{w} / \mathrm{w}$ ). The inocula were sieved after collection, through a $2 \mathrm{~mm}$ net to remove large particles and then were kept in incubators at the corresponding temperatures. Table 1 illustrates the basic characteristics of both inocula. 
Basic anaerobic medium (BA-medium) was used for both inocula (Angelidaki et al., 1990) with the exception that all carbon sources (e.g., $\mathrm{NaHCO}_{3}$ and glucose) were omitted to minimize the interference of carbon species during the fermentation.

\subsection{Experimental setup}

All the fermentative experiments were carried out in triplicate using $540 \mathrm{~mL}$ serum bottles with $100 \mathrm{~mL}$ working volume and $10 \%(\mathrm{v} / \mathrm{v})$ inocula. The bottles with the BA-media were sealed with butyl rubber stopper and aluminium cap and then sterilized at $121^{\circ} \mathrm{C}$ and 15 psi for $20 \mathrm{~min}$. After sterilization, vitamin solution was added using $0.2 \mu \mathrm{m}$ sterilized filter. Before inoculation the serum bottles were reduced with sodium sulphide solution to a final concentration of $0.25 \mathrm{~g} / \mathrm{L} .2 \mathrm{~N} \mathrm{KOH}$ and $2 \mathrm{~N} \mathrm{HCl}$ solutions had been used to adjust the initial $\mathrm{pH}$ of the medium at $6.0 \pm 0.1$. All the serum bottles were incubated horizontally in an IKA ${ }^{\circledR}$ KS 4000i control orbital shaker at $37 \pm 1^{\circ} \mathrm{C}$ for mesophilic and $55 \pm 1^{\circ} \mathrm{C}$ for thermophilic conditions and with $150 \mathrm{rpm}$ constant speed.

\subsubsection{Screening experiment: effect of heat treatment methods}

Inhibition of methanogenic archaea in inocula was a crucial step in the present study. Therefore, batch experiments were performed to study the effect of thermal treatment of the different inocula on the microbial community and biochemical production. For the thermal treatment, the inocula were heat shocked at $90^{\circ} \mathrm{C}$ for $30 \mathrm{~min}$, followed by cooling to room temperature (Nam et al., 2016). After treatment, the inocula were kept in the incubators at their corresponding temperature. The treated inocula were then fed with a synthetic gas composition $\left(\mathrm{H}_{2}: \mathrm{CO}_{2}: \mathrm{CH}_{4}, 2: 1: 1.5\right)$ to a final pressure of 1.5 bar.

\subsubsection{Optimization experiment: effect of different gas ratios}

Based on the results from the screening experiments, a selected inoculum was taken up for further study to investigate the influence of different gas ratios on biogas upgrading and 
biochemical production process. The selected inoculum was fed with a mixture of biogas $\left(40 \% \mathrm{CO}_{2}: 60 \% \mathrm{CH}_{4}\right)$ and pure $(100 \%) \mathrm{H}_{2}$. The difference between the four gas ratios $\left(\mathrm{GR}_{1-}\right.$ 4x) was based on different ratios between $\mathrm{H}_{2}$ and $\mathrm{CO}_{2}$. The four feed gas composition was GR (1x): $\left(\mathrm{H}_{2} / \mathrm{CO}_{2} / 1.5 \mathrm{CH}_{4}\right), \mathrm{GR}(2 \mathrm{x}):\left(2 \mathrm{H}_{2} / \mathrm{CO}_{2} / 1.5 \mathrm{CH}_{4}\right), \mathrm{GR}(3 \mathrm{x}):\left(3 \mathrm{H}_{2} / \mathrm{CO}_{2} / 1.5 \mathrm{CH}_{4}\right)$ and GR (4x): $\left(4 \mathrm{H}_{2} / \mathrm{CO}_{2} / 1.5 \mathrm{CH}_{4}\right)$, respectively. For the controls, the mixed cultures were kept under $100 \% \mathrm{~N}_{2}$ in the headspace without presence of other gases.

\subsection{Analytical methods}

A digital PHM210 pH meter connected to the Gel pH electrode (pHC3105-8; Radiometer analytical) was used to measure $\mathrm{pH}$ of samples. Standard Methods were applied for total ammonia $\left(\mathrm{NH}_{4}^{+}-\mathrm{N}\right)$, total Kjeldahl nitrogen (TKN), total solid (TS) and volatile solid (VS) determination (APHA, 2005). The gas chromatograph (Shimadzu GC-2010, Kyoto, Japan) was used to determine the volatile fatty acid samples that prepared as previously described (Symsaris et al., 2015). The $\mathrm{CH}_{4}$ and $\mathrm{CO}_{2}$ content in headspace gas samples were measured with a gas-chromatograph (Thermoscientific GC-8A, Japan), while the $\mathrm{H}_{2}$ gas was determined with a gas chromatograph (Shimadzu GC-11A, Tokyo-Japan). The characteristics of both GC were previously described (Omar et al., 2018). Triplicate samples were analysis for the all processes.

\subsection{Microbial analysis}

RNA PowerSoil® DNA Elution Accessory Kits (MO BIO Laboratories, Carlsbad, CA) were used for the extraction and purification of genomic DNA from thermophilic inocula (untreated and thermal treated) and liquid samples from the optimisation process. Animal fibers residues were initially eliminated by filtering the samples through a $100 \mu$ m nylon cell strainer filter. Afterward, samples were purified using (Phe: Chl: IAA) solutions. Evaluation 
of the quantity and the quality of extracted DNA was performed using Qbit fluorimeter (Life Technologies, Carlsbad, CA) and NanoDrop (ThermoFisher Scientific, Waltham, MA).

Through the current study, BA01 and BA02 were referred to untreated and treated inoculum at $90^{\circ} \mathrm{C}$, respectively. While, BA03, BA04, BA05, BA06 and BA07 were referred to treated inoculum (at $90^{\circ} \mathrm{C}$ ) exposed to different gas ratio $\mathrm{GR}_{(1 \mathrm{x})}, \mathrm{GR}_{(2 \mathrm{x})}, \mathrm{GR}_{(3 \mathrm{x})}, \mathrm{GR}_{(4 \mathrm{x})}$ and control samples (without fermentation gas), respectively. Samples were then sequenced in the Ramaciotti Centre for Genomics (UNSW, Sydney) where MiSeq platform (Illumina) and universal primers 515F/806R were used. CLC Workbench software (V.8.0.2) with microbial genomics module plug in (QIAGEN) was used for Bioinformatics' analyses conduction on raw data (Kougias et al., 2017). Raw reads were deposited in Sequence Read Archive (SRA) database (http://www.ncbi.nlm.nih.gov/sra) under the project number PRJNA388850 (Esupplementary data for this work can be found in e-version of this paper online).

\subsection{Statistical analyses and calculation}

The obtained data were analysed statistically by ANOVA with F test. Comparison of treatment means was performed using MSTAT-C statistical computer package (Michigan State University, East Lansing, MI, USA) with Duncan's multiple range Test. The figure was performed by the OriginLab program (OriginLab Corporation, Northampton, Massachusetts). The calculations of mass balance through the current study were depended on the Chemical Oxygen Demand (COD) balance. 


\section{Results and Discussion}

\subsection{Effect of different treatment methods on upgrading and chemical production processes}

The effect of heating treatment of the different inocula on the fermentation process was primarily evaluated in terms of hydrogen consumption, $\mathrm{pH}$ and VFA production. Under the thermophilic condition, there was a lag phase of five days, after which $\mathrm{H}_{2}$ utilisation increased rapidly till reached to the maximum consumption of $86 \%$ after 12 days of incubation (Fig. 1a). In contrast, the mesophilic inoculum has shown a poor adaptation to the gas mixture. The different behaviour of the both inoculum could be attributed to the different diversity in microbial population and cell density after heating pre-treatment (Wang and Wan, 2008). Wang and Yin (2017) investigated the influence of temperature on the microbial survival and reported various significant effects of the high temperature on the bacteria such as deterioration of microbial protein, disruption of the chemical bonds of the cell wall and membrane and solubilization of the cell components. Another reason for the low adaptation of the mesophilic inoculum to fermentation condition could be the absence of spore-forming bacteria that can resist the high temperature.

VFA profile is another indicator of the ability of thermophilic inoculum to achieve the main goal of the present study. Acetate was the main metabolite produced by the thermophilic inoculum with maximum net production of $504.2 \mathrm{mg} / \mathrm{L}$ (Fig. 1b), while the mesophilic inoculum produced significantly lower concentration $(44 \mathrm{mg} / \mathrm{L})(p<0.05)$. The maximum acetate productivity under the thermophilic condition was 86 fold of that produced in the control, which confirmed that acetate was mainly produced from $\mathrm{CO}_{2}$ and $\mathrm{H}_{2}$ fermentation. On the contrary, non-significant difference between control and the tests under the mesophilic condition was observed $(\mathrm{p}<0.05)$. The maximum acetate concentration 
achieved through the current study was lower than that previously reported (Wang et al., 2017). The enhancement of the liquid-gas mass transfer which leads to a high utilization of $\mathrm{H}_{2}$ was the main reason for the relatively higher acetate production in previous study. In addition, using a highly effective inhibitor to methanogens (e.g., BES) in that study was another important reason contributing to the enhancement of acetate production. While, the heating treatment of the thermophilic inoculum through the current study did not completely block the activity of methanogens which significantly affected the productivity of acetate due to the ability of methanogens to use $\mathrm{H}_{2}-\mathrm{CO}_{2}$ directly or generated acetate indirectly to produce methane (Kimmel et al., 1991).

The significant difference in the behaviour of the both inocula reflected also on the $\mathrm{pH}$ fluctuation throughout the test (Fig.1c). Under the thermophilic condition, $\mathrm{pH}$ increased after four days from 6 to 7 and then started to decrease due to the accumulation of acetate until reached 5 at the end of experiment, while non-significant difference $(\mathrm{p}>0.05)$ of $\mathrm{pH}$ was observed in the mesophilic condition and also in the control reactor. Thus, the thermophilic mixed culture after heating pre-treatment was selected for the following experiments.

\subsection{Effect of $\mathrm{H}_{2} / \mathrm{CO}_{2}$ ratios on the thermophilic fermentation process}

\subsubsection{Biochemical production and $\mathrm{pH}$ profile}

Through the thermophilic fermentation, acetate was the most dominant product at all tested gas ratios. The acetate production started after four days of inoculation by the thermophilic inoculum and then rapidly increased till the end of fermentation, which was consistent with the rapid consumption of hydrogen gas illustrated in Fig. 2. There was a significant difference between the samples and the control in the production of acetate, as the maximum acetate produced at $\mathrm{GR}_{(2 \mathrm{x})}$ was 78 fold of that produced in the control bottles. The highest acetate yield of $72 \%$ was achieved at $\mathrm{GR}_{(2 \mathrm{x})}$ (Table 2), which was also consistent with the consumption of $\mathrm{H}_{2}$ shown in Fig. 2. The COD balance is illustrated in Table 2. The 
presence of methanogens in the thermophilic inoculum was the main reason for the lower acetate production in the present study comparing to other fermentation process in previous studies (Savage and Drake, 1986; Sakai et al., 2005; Kim et al., 2016 ; Wang et al., 2017). (Esupplementary data for this work can be found in e-version of this paper online). The uninhibited methanogens after heating pre-treatment could compete with acetogens for $\mathrm{H}_{2}$ and $\mathrm{CO}_{2}$ and produce $\mathrm{CH}_{4}$ (Wang et al., 2017). The rapid increase in the consumption of the gaseous substrate and accumulation of acetate had a significant influence on the $\mathrm{pH}$ values. $\mathrm{pH}$ increased from 6 to 7 with the all gas ratios till the fourth day, after which the values started to decrease due to the accumulation of acetate (Table 2). The lowest $\mathrm{pH}$ was observed at $\mathrm{GR}_{(2 \mathrm{x})}$ which could be due to the highest acetate concentration over other gas ratios. $\mathrm{GR}_{(1 \mathrm{x})}$ had a higher final $\mathrm{pH}$, which could be due to the less available electron donor (i.e., $\mathrm{H}_{2}$ ) for acetate production. In the control, $\mathrm{pH}$ increased through the first four days from 6.1 to 7.65 and remained stable till the end of the experiment.

\subsubsection{Biogas upgrading}

The maximum biomethane concentration of $77 \%(\mathrm{v} / \mathrm{v})$ was achieved at $\mathrm{GR}_{(2 \mathrm{x})}$ after 12 days of incubation (Fig. 3). $\mathrm{GR}_{(3 \mathrm{x})}$ and $\mathrm{GR}_{(4 \mathrm{x})}$ achieved maximum biomethane concentration of $56 \%$ and $39 \%$ which was significantly $(p<0.05) 26.7 \%$ and $49.5 \%$ lower than $\operatorname{GR}_{(2 x)}(p<$ 0.05). This was associated with the high consumption of both $\mathrm{CO}_{2}$ and $\mathrm{H}_{2}$ at $\mathrm{GR}_{(2 \mathrm{x})}$ with $8.95 \% \mathrm{CO}_{2}$ and $13.98 \% \mathrm{H}_{2}$ left (Fig. 3). Moreover, this gas ratio achieved the maximum yield of acetate (Table 2). However, the difference in maximum concentration of biomethane between $\mathrm{GR}_{(1 \mathrm{x})}$ and $\mathrm{GR}_{(2 \mathrm{x})}$ was non-significant $(\mathrm{p}>0.05)$, but the relative concentration of lefted $\mathrm{CO}_{2}$ at $\mathrm{GR}_{(2 \mathrm{x})}$ was $61 \%$ lower than lefted at $\mathrm{GR}_{(1 \mathrm{x})}$. The biogas upgrading efficiency in the current study was lower than that achieved by the other biological biogas upgrading techniques. Methane concentration above $96 \%$ with $\left(<4 \%\right.$ and $<0.1 \%$ residual $\mathrm{CO}_{2}$ and $\mathrm{H}_{2}$, respectively) was achieved through biogas upgrading process using hydrogenotrophic 
community in a trickle-bed reactor (Rachbauer et al., 2016). In another microbial upgrading technique performed by microalgae Chlorella sp., $\mathrm{CH}_{4}$ concentration in upgraded biogas reach to $93.7 \%$ with $1.57 \% \mathrm{CO}_{2}$ left (Yan and Zheng, 2014). Compared to the gas quality standards regarding to biogas utilization, the upgraded biogas from the current study cannot be used a vehicle fuel or injected into natural gas grids, due to its lower methane content and higher content of $\mathrm{H}_{2}$ and $\mathrm{CO}_{2}$ (Sun et al., 2015b). The incomplete inhibition of methanogenic archaea by thermal treatment was the main reason of lower biogas upgrading and acetate production compared to the other studies. However, the upgraded biogas from the current study can be used in a new class of power-generation technologies (fuel cells) which converting chemical energy of fuels directly and with relatively high efficiency in to electricity at reduced harmful emissions (Budzianowski, 2016).

\subsection{Microbial community composition through the optimization processes}

Alpha diversity based on the number of operational taxonomic units (OTUs) showed that the sequencing depth was adequate to cover the microbial species richness (E-supplementary data for this work can be found in e-version of this paper online). The thermal treatment of the inoculum and different gas ratios significantly affected the complexity of the microbial community. The lowest microbial complexity was observed in the control (BA07), while the highest was observed with preheated sample at $90^{\circ} \mathrm{C}$ (BA02). All the microbial communities exposed to thermal treatment and different gas ratios and the abundance of the identified OTUs were represented by phylogenetic tree (Fig. 4) and a heat map (Fig. 5). The significant effect of the thermal treatment and different gas ratios were also clarified by principal coordinate analyses (PCoA) (E-supplementary data for this work can be found in e-version of this paper online). 


\subsubsection{Effect of thermal treatment on microbial community}

The thermal treatment of the inoculum has significantly affected the microbial community. The most dominant bacterium in the untreated inoculum (from the Biogas Plant), BA01, was Bacteroidales sp. 16 (27.12\%) following by MBA08 sp. 1(6.74\%) and Syntrophaceticus schinkii 51 (6.72\%). MBA08 cluster was previously reported in thermophilic garbage digester (Cheon et al., 2007), thermophilic manure based biogas reactors processing straw (Sun et al., 2013) and thermophilic ex-situ biogas upgrading reactor (Kougias et al., 2017). After thermal treatment, the relative abundance of $M B A 08$ sp. 1 was 4.75 fold compared to the untreated inoculum, while the abundance of Bacteroidales sp.16 in untreated inoculum was 1.71 fold compared to the treated one, which reflected the significant effect of treatment on the different microbes. Similar trends had been also reported in previous studies (Sun et al., 2013; Sun et al., 2015a; Ziganshin et al., 2013). Increasing temperature degrees through these studies led to an increase in the relative abundance of Clostridia affiliates and a decrease in the relative abundance of Bacteroidetes. In addition, the relative abundance of Anaerobacillus macyae 40 (Phylum Firmicutes) was 8.16 fold compared to that in the untreated inoculum. A. macyae has the ability to form resistant endospores, allowing this bacterium to survive for a prolonged period of time in adverse circumstances (Wang et al., 2015).

\subsubsection{Effect of different gas ratios on the microbial composition}

Through the second batch experiment, the gas composition had a significant influence on the microbial community compared to control samples (BA07). Based on 16S rRNA sequence analysis, Clostridium caenicola 75 was the most dominant bacterium in the control and was $100 \%$ sequence similarity to Clostridium caenicola. This obligatory anaerobic, thermophilic and chemo-organotrophic bacterium was isolated from anaerobic sludge of a cellulose-degrading methanogenic bioreactor (Shiratori et al., 2009). Clostridia sp.10 and 
MBA08 sp. 1 were the second most abundant bacteria with a relative abundance of $13.02 \%$ and $13.65 \%$, respectively. By performing a BLASTn search against the NCBI database (16S rRNA sequence database), these bacteria were $91 \%$ and $90 \%$, respectively similar to "Hydrogenispora ethanolica" which was newly identified as a carbohydrate-fermenting bacterium (Liu et al., 2014). Moreover, exposing the samples to different gas ratio led to a significant difference in the composition of the microbial community. Moorella sp. 4 was the most dominant bacterium in the samples with gas ratio $\mathrm{GR}_{(2 \mathrm{x})}(\mathrm{AB} 04)$ and $\mathrm{GR}_{(3 \mathrm{x})}(\mathrm{AB} 05)$ with a relative abundance of $23.38 \%$ and $28.92 \%$, respectively. This dominant bacterium was 99\% sequence similarity to both Moorella thermoacetica and Moorella thermoautotrophica. These thermophilic model acetogenic bacteria have been studied extensively for their ability to reductively synthesize acetate from $\mathrm{CO}_{2}$ via the acetyl-CoA pathway (Hu et al., 2013; Redl and Nielsen, 2016; Seifritz et al., 1999). While the relative abundance of this acetogenic bacterium was lower in samples with other gas ratio $\mathrm{GR}_{(1 \mathrm{x})}(\mathrm{AB} 03)$ and $\mathrm{GR}_{(4 \mathrm{x})}(\mathrm{AB} 06)$ and was completely absent in the control samples (AB07). The relative abundance of MBA08 sp.1 (Phylum Firmicutes) was high in all gas ratio and control, except the sample with gas ratio $\mathrm{GR}_{(3 \mathrm{x})}(\mathrm{AB} 05)$ which achieved the lowest relative abundance $(2.25 \%)$ of this bacterium . BLASTn search against the NCBI database (16S rRNA sequence database) revealed $90 \%$ similarity to the newly identified carbohydrate-fermenting bacterium "Hydrogenispora ethanolica" (Liu et al., 2014). As the sequence identity score was less than the genera classification threshold (>94.5\%), the taxonomy of this OTU remains uncertain, suggesting this microorganism as a new species (Yarza et al., 2014). However the high abundance of this microbe revealed important function through the fermentation process.

Thermoanaerobacterium sp.11 was another interesting bacterium that observed in all gas ratios with a lowest relative abundance $(0.09 \%)$ in $(\mathrm{AB} 03)$ and was completely absent in the control samples (AB07). This interesting bacterium was $100 \%$ similar to 
Thermoanaerobacterium xylanolyticum/Thermoanaerobacterium thermosaccharolyticum/Thermoanaerobacterium calidifontis compared to the NCBI database. Thermoanaerobacterium (Phyla Firmicutes) are obligate anaerobic fermentative microorganisms and also reported as hydrogen-producing bacteria under thermophilic conditions (Ratti et al., 2015).Thermophilic anaerobic bacteria like Thermoanaerobacterium and Moorella spp. are usually habitated in numerous hot environments such as: geothermal hot springs and hydrothermal vents or sometimes warm environments like compost and manure (André et al., 2013). Thermoanaerobacterium and Moorella spp. were observed in assays for $\mathrm{H}_{2}$ production by thermophilic anaerobic microflora (Ueno et al., 2006). The presence of fermentation gases also stimulated the activity of methanogenic archaea "Methanosarcina thermophila 1 " which was observed in all gas ratios with maximum relative abundance of $1.74 \%$ for $\mathrm{BA} 05$, while $\mathrm{BA} 04$ has shown the lowest relative abundance of $M$. thermoacetica $(0.8 \%)$ which explains the highest acetate yield achieved by this gas ratio (Table 2). M. thermophila 1 can grow on acetate, methanol, or methylated amines and can also grow slowly on $\mathrm{H}_{2}$ : $\mathrm{CO}_{2}$, which explain the methane production through the fermentation process and the lower acetate productivity compared to other studies (Zinder et al., 1985).

\subsection{Future directions for improving the biogas upgrading and biochemical production process}

The present study provided a new method for biogas upgrading and VFA production through the mixed culture fermentation of $\mathrm{CO}_{2}$ and $\mathrm{H}_{2}$. However, further improvement should be applied to enhance the efficiency of both processes. These improvements including: 
- Treatment method: Using other pre-treatment methods (e.g., chemical treatment) that are more efficient for methanogenesis inhibition and enriching acetogenic bacteria.

- Biocatalyst type: Providing the process with effluents from other anaerobic reactor using acetogenic bacteria for the production of VFAs and alcohols. By using these enriched bacteria, pre-treatment step and its related problems (e.g., cost) can be omitted.

- Gas liquid mass transfer: Increasing the availability of $\mathrm{H}_{2}$ to the acetogenic bacteria is another significant factor that can enhance the efficiency of the whole process. Replacing batch system with reactor provided with gas dispersion systems (e.g. hollow fibre membranes) can guarantee high mass transfer rates of $\mathrm{H}_{2}$ gas and thus increases the productivity of the process.

Applying these suggested improvements on the present novel method can open new avenues in the bioenergy field.

\section{Conclusions}

Through the current study, a novel bioprocess for chemicals production and biogas upgrading was optimised. This new bioprocess was based on the fermentation of $\mathrm{CO}_{2}$ and $\mathrm{H}_{2}$ to valuable chemicals (e.g., acetate) by acetogenic mixed culture. The effects of thermal treatment of two different inocula on the microbial community and biochemical production was initially investigated under thermophilic and mesophilic condition. Thermophilic inoculum has shown higher ability to inhibit methanogenesis and produced higher acetate compared to mesophilic inoculum. Thermophilic fermentation by the gas ratio $2 \mathrm{H}_{2}: 1 \mathrm{CO}_{2}$ achieved the maximum biogas content and acetate yield compared to the other gas ratios.

\section{"E-supplementary data for this work can be found in e-version of this paper online".}




\section{Acknowledgements}

Hector Garcia was thankful for technical support. Novo Nordisk Foundation (NNF16OC0021568) and Danish Council for Independent Research (DFF-1335-00142) had been corroborative financially this research. The Ministry of Higher Education of Egypt is gratefully acknowledged for $\mathrm{PhD}$ channel mission to the first author. The authors are grateful to Dr. Panagiotis Kougias and Dr. Laura Treu for helping in microbiological data analysis.

\section{References}

[1]. Abdeen, F.R.H., Mel, M., Jami, M.S., Ihsan, S.I., Ismail, A.F., 2016. A review of chemical absorption of carbon dioxide for biogas upgrading. Chinese J. Chem. Eng. 24, 693-702. https://doi.org/10.1016/j.cjche.2016.05.006

[2]. André, S., Zuber, F., Remize, F., 2013. Thermophilic spore-forming bacteria isolated from spoiled canned food and their heat resistance. Results of a French ten-year survey. Int. J. Food Microbiol. 165, 134-143. https://doi.org/10.1016/j.ijfoodmicro.2013.04.019

[3]. Angelidaki, I., Petersen, S.P., Ahring, B.K., 1990. Effects of lipids on thermophilic anaerobic digestion and reduction of lipid inhibition upon addition of bentonite. Appl. Microbiol. Biotechnol. 33, 469-472. https://doi.org/10.1007/BF00176668

[4]. Angelidaki, I., Treu, L., Tsapekos, P., Luo, G., Campanaro, S., Wenzel, H., Kougias, P.G., 2018. Biogas upgrading and utilization: Current status and perspectives. Biotechnol. Adv. 36, 452-466. https://doi.org/10.1016/j.biotechadv.2018.01.011

[5]. APHA, 2005. Standard Methods for the Examination of Water and Wastewater. American Public Health Association, USA.

[6]. Awe, O.W., Zhao, Y., Nzihou, A., Minh, D.P., Lyczko, N., 2017. A Review of Biogas Utilisation, Purification and Upgrading Technologies. Waste Biomass Valor. 8, 267- 
283. https://doi.org/10.1007/s12649-016-9826-4

[7]. Bassani, I., Kougias, P.G., Angelidaki, I., 2016. In-situ biogas upgrading in thermophilic granular UASB reactor: key factors affecting the hydrogen mass transfer rate. Bioresour. Technol. 221, 485-491. https://doi.org/10.1016/j.biortech.2016.09.083

[8]. Budzianowski, W.M., 2016. A review of potential innovations for production, conditioning and utilization of biogas with multiple-criteria assessment. Renew. Sustain. Energy Rev. 54, 1148-1171. https://doi. org/10.1016/j.rser.2015.10.054

[9]. Cheon, J., Hong, F., Hidaka, T., Koshikawa, H., A., Tsuno, H., 2007. Microbial population dynamics in a thermophilic methane digester fed with garbage. Water Sci. Technol. 55, 175-182.

[10]. Fernández-naveira, Á., Veiga, M.C., Kennes, C., 2017. H-B-E (hexanol-butanolethanol) fermentationfor the production of higher alcohols from syngas / waste gas. J. Chem. Technol. Biotechnol. 92, 712-731. https://doi.org/10.1002/jctb.5194

[11]. Hu, P., Rismani-yazdi, H., Stephanopoulos, G., 2013. Anaerobic $\mathrm{CO}_{2}$ Fixation by the Acetogenic Bacterium Moorella thermoacetica. AICHE Journal 59(9), 3176-3183. https://doi. org/10.1002/aic.14127

[12]. Kimmel, D., Klasson, K., Clausen, E., Gaddy, J., 1991. Performance of tirckle-bed bioreactors for converting synthesis gas to methane. Appl. Biochem. Biotechnol. 28, 457-469. https://doi.org/10.1007/bf02922625

[13]. Kokkoli, A., Zhang, Y., Angelidaki, I., 2018. Microbial electrochemical separation of $\mathrm{CO}_{2}$ for biogas upgrading. Bioresour.Technol. 247, 380-386. https://doi.org/10.1016/j. biortech.2017.09.097

[14]. Kougias, P.G., Treu, L., Benavente, D.P., Boe, K., Campanaro, S., Angelidaki, I., 2017. Ex-situ biogas upgrading and enhancement in different reactor systems. Bioresour. Technol. 225, 429-437. https://doi.org/10.1016/j.biortech.2016.11.124 
[15]. Leonzio, G., 2016. Upgrading of biogas to bio-methane with chemical absorption process: Simulation and environmental impact. J. Clean. Prod. 131, 364-375. https://doi.org/ 10.1016/j.jclepro.2016.05.020

[16]. Liew, F., Henstra, A.M., Winzer, K., Köpke, M., Simpson, S.D., Minton, N.P., 2016. Insights into $\mathrm{CO}_{2}$ fixation pathway of Clostridium autoethanogenum by targeted mutagenesis. MBio 7(3), 416-427. https://doi.org/10.1128/mBio.00427-16

[17]. Liu, Y., Qiao, J., Yuan, X., Guo, R., Qiu, Y., 2014. Hydrogenispora ethanolica gen. nov., sp. nov., anaerobic carbohydrate-fermenting bacterium from anaerobic sludge. Int. J. Syst. Evol. Microbiol. 64, 1756-1762. https://doi.org/10.1099/ijs.0.060186-0

[18]. Luo, G., Angelidaki, I., 2012. Integrated biogas upgrading and hydrogen utilization in an anaerobic reactor containing enriched hydrogenotrophic methanogenic culture. Biotechnol. Bioeng 109, 2729-2736.

[19]. Micale, C., 2015. Bio-methane generation from biogas upgrading by semi-permeable membranes: An experimental, numerical and economic analysis. Energy Procedia 82, 971-977. https://doi.org/10.1016/j.egypro.2015.11.854

[20]. Nam, C.W., Jung, K.A., Park, J.M., 2016. Biological carbon monoxide conversion to acetate production by mixed culture. Bioresour. Technol. 211, 478-485. https://doi.org/10.1016/ j.biortech.2016.03.100

[21]. Omar, B., Abou-shanab, R., El-gammal, M., Fotidis, I.A., Kougias, P.G., Zhang, Y., Angelidaki, I., 2018. Simultaneous biogas upgrading and biochemicals production using anaerobic bacterial mixed cultures. Water Res. 142, 86-95. https://doi.org/10. 1016/ j.watres.2018.05.049

[22]. Rachbauer, L., Voitl, G., Bochmann, G., Fuchs, W., 2016. Biological biogas upgrading capacity of a hydrogenotrophic community in a trickle-bed reactor. Appl. Energy 180, 483-490. https://doi.org/10.1016/j.apenergy.2016.07.109 
[23]. Ratti, R.P., Delforno, T.P., Okada, D.Y., Varesche, M.B.A., 2015. Bacterial communities in thermophilic $\mathrm{H}_{2}$-producing reactors investigated using 16S rRNA 454 pyrosequencing. Microbiol. Res. 173, 10-17. https://doi.org/10.1016/j.micres.2015. 01.010

[24]. Redl, S., Diender, M., Ølshøj, T., Sousa, D.Z., Toftgaard, A., 2017. Exploiting the potential of gas fermentation. Ind. Crops Prod. 106, 21-30.

[25]. Redl, S.M.A., Nielsen, A.T., 2016. Gas Fermentation using Thermophilic Moorella Species for production of Biochemicals. PhD thesis, Novo Nordisk Foundation Center for Biosustainability, Technical University of Denmark, Denmark.

[26]. Rotunno, P., Lanzini, A., Leone, P., 2017. Energy and economic analysis of a water scrubbing based biogas upgrading process for biomethane injection into the gas grid or use as transportation fuel. Renew. Energy 102, 417-432. https://doi.org/10.1016/j. renene.2016.10.062

[27]. Schiel-Bengelsdorf, B., Dürre, P., 2012. Pathway engineering and synthetic biology using acetogens. FEBS Lett. 586, 2191-2198. https://doi.org/10.1016/j.febslet.2012. 04.043

[28]. Seifritz, C., Drake, H.L., Daniel, S.L., Fro, M., 1999. Glycolate as a metabolic substrate for the acetogen Moorella thermoacetica. FEMS Microbiol. Lett. 170(2), 399-405.

[29]. Shiratori, H., Sasaya, K., Ohiwa, H., Ikeno, H., Ayame, S., Kataoka, N., Miya, A., Beppu, T., Ueda, K., 2009. Clostridium clariflavum sp. nov. and Clostridium caenicola sp. nov., moderately thermophilic, cellulose-/cellobiose-digesting bacteria isolated from methanogenic sludge. Int. J. Syst. Evol. Microbiol. 59, 1764-1770. https://doi.org/ 10.1099/ijs.0.003483-0

[30]. Sun, L., Müller, B., Schnürer, A., 2013. Biogas production from wheat straw: Community structure of cellulose-degrading bacteria. Energy. Sustain. Soc. 3. 
https://doi.org/10. 1186/2192-0567-3-15

[31]. Sun, L., Pope, P.B., Eijsink, V.G.H., Schnürer, A., 2015a. Characterization of microbial community structure during continuous anaerobic digestion of straw and cow manure. Microb Biotechnol. 8(5), 815-827. https://doi.org/10.1111/1751-7915.12298

[32]. Sun, Q., Li, H., Yan, J., Liu, L., Yu, Z., Yu, X., 2015b. Selection of appropriate biogas upgrading technology-a review of biogas cleaning, upgrading and utilisation. Renew. Sustain. Energy Rev. 51, 521-532. https://doi.org/10.1016/j.rser.2015.06.029

[33]. Symsaris, E.C., Fotidis, I.A., Stasinakis, A.S., Angelidaki, I., 2015. Effects of triclosan, diclofenac, and nonylphenol on mesophilic and thermophilic methanogenic activity and on the methanogenic communities. J. Hazard. Mater. 291, 45-51. https://doi.org/10. 1016/j.jhazmat.2015.03.002

[34]. Toledo-Cervantes, A., Serejo, M.L., Blanco, S., Pérez, R., Lebrero, R., Muñoz, R., 2016. Photosynthetic biogas upgrading to bio-methane: Boosting nutrient recovery via biomass productivity control. Algal Res. 17, 46-52. https://doi.org/10.1016/ j.algal.2016.04.017

[35]. Ueno, Y., Sasaki, D., Fukui, H., Haruta, S., Ishii, M., Igarashi, Y., 2006. Changes in bacterial community during fermentative hydrogen and acid production from organic waste by thermophilic anaerobic microflora. J. Appl. Microbiol. 101, 331-343. https://doi.org/ 10.1111/j.1365-2672.2006.02939.x

[36]. Wang, J., Liu, B., Liu, G., Ge, C., Chen, Q., Zhu, Y., Chen, Z., 2015. Genome Sequence of Anaerobacillus macyae JMM-4T (DSM 16346), the First Genomic Information of the Newly Established Genus Anaerobacillus. Genome Announc. 3(4), 915-922. https:// doi.org/10.1128/genomeA.00922-15.

[37]. Wang, J., Yin, Y., 2017. Principle and application of different pretreatment methods for enriching hydrogen-producing bacteria from mixed cultures. Int. J. Hydrogen Energy 
42(8), 4804-4823. https://doi.org/10.1016/j.ijhydene.2017.01.135

[38]. Wang, J.L., Wan, W., 2008. Comparison of different pretreatment methods for enriching hydrogen-producing bacteria from digested sludge. Int. J. Hydrogen Energy 33, 2934-2941. https://doi.org/10.1016/j.ijhydene.2008.03.048

[39]. Wang, Y.-Q., Yu, S.-J., Zhang, F., Xia, X.-Y., Zeng, R.J., 2017. Enhancement of acetate productivity in a thermophilic $\left(55^{\circ} \mathrm{C}\right)$ hollow-fiber membrane biofilm reactor with mixed culture syngas $\left(\mathrm{H}_{2} / \mathrm{CO}_{2}\right)$ fermentation. Appl. Microbiol. Biotechnol. 101(6), 2619-2627. https://doi.org/10.1007/s00253-017-8124-9

[40]. Yan, C., Muñoz, R., Zhu, L., Wang, Y., 2016. The effects of various LED (light emitting diode) lighting strategies on simultaneous biogas upgrading and biogas slurry nutrient reduction by using of microalgae Chlorella sp. Energy 106, 554-561. https://doi.org/ 10.1016/j.energy.2016.03.033

[41]. Yan, C., Zheng, Z., 2014. Performance of mixed LED light wavelengths on biogas upgrade and biogas fluid removal by microalga Chlorella sp. Appl. Energy 113, 10081014. https://doi.org/10.1016/j.apenergy.2013.07.012

[42]. Yarza, P., Yilmaz, P., Pruesse, E., Glöckner, F.O., Ludwig, W., Schleifer, K.-H., Whitman, W.B., Euzéby, J., Amann, R., Rosselló-Móra, R., 2014. Uniting the classification of cultured and uncultured bacteria and archaea using 16S rRNA gene sequences. Nat. Rev. Microbiol. 12, 635-645.

[43]. Ziganshin, A.M., Liebetrau, J., Pröter, J., Kleinsteuber, S., 2013. Microbial community structure and dynamics during anaerobic digestion of various agricultural waste materials. Appl. Microbiol. Biotechnol. 97(11),5161-5174. https://doi.org/10.1007/ s00253-013-4867-0

[44]. Zinder, S.H., Sowers, K.R., Ferry, A.N.D.J.G., 1985. Methanosarcina thevmophila sp. nov. a Thermophilic, Acetotrophic, Methane-Producing Bacterium. Int. J. Syst. 
Bacteriol. 35, 522-523. 


\section{Figure Captions}

Fig.1 a) $\mathrm{H}_{2}$ consumption, b) acetate production and c) $\mathrm{pH}$ fluctuation in the mesophilic and thermophilic inocula experiments.

Fig. 2 Hydrogen consumption profile at the different gas ratios.

Fig. 3 The relative concentration of the three gases through the fermentation process under different gas ratios: A) $\left.\left.\mathrm{GR}_{(1 \mathrm{x})}\left(\mathrm{H}_{2}: \mathrm{CO}_{2}\right), \mathrm{B}\right) \mathrm{GR}_{(2 \mathrm{x})}\left(2 \mathrm{H}_{2}: \mathrm{CO}_{2}\right), \mathrm{C}\right) \mathrm{GR}_{(3 \mathrm{x})}\left(3 \mathrm{H}_{2}: \mathrm{CO}_{2}\right)$, and D) $\mathrm{GR}_{(4 \mathrm{x})}\left(4 \mathrm{H}_{2}: \mathrm{CO}_{2}\right)$, respectively.

Fig. 4 Phylogenetic tree of the complete microbial community of the thermophilic inoculum before and after thermal treatment and after exposing to different gas ratio.

Fig. 5 Heat map representing the OTUs with the higher abundance in the samples. The gradient scale above the heat map illustrates the correspondence between the colours and relative abundance. 


\section{Tables}

Table 1 Characteristics of the mesophilic and thermophilic inocula used in this study.

Table 2 COD balance and fermentation performance of the pre-treated thermophilic inoculum at various gas ratios. 

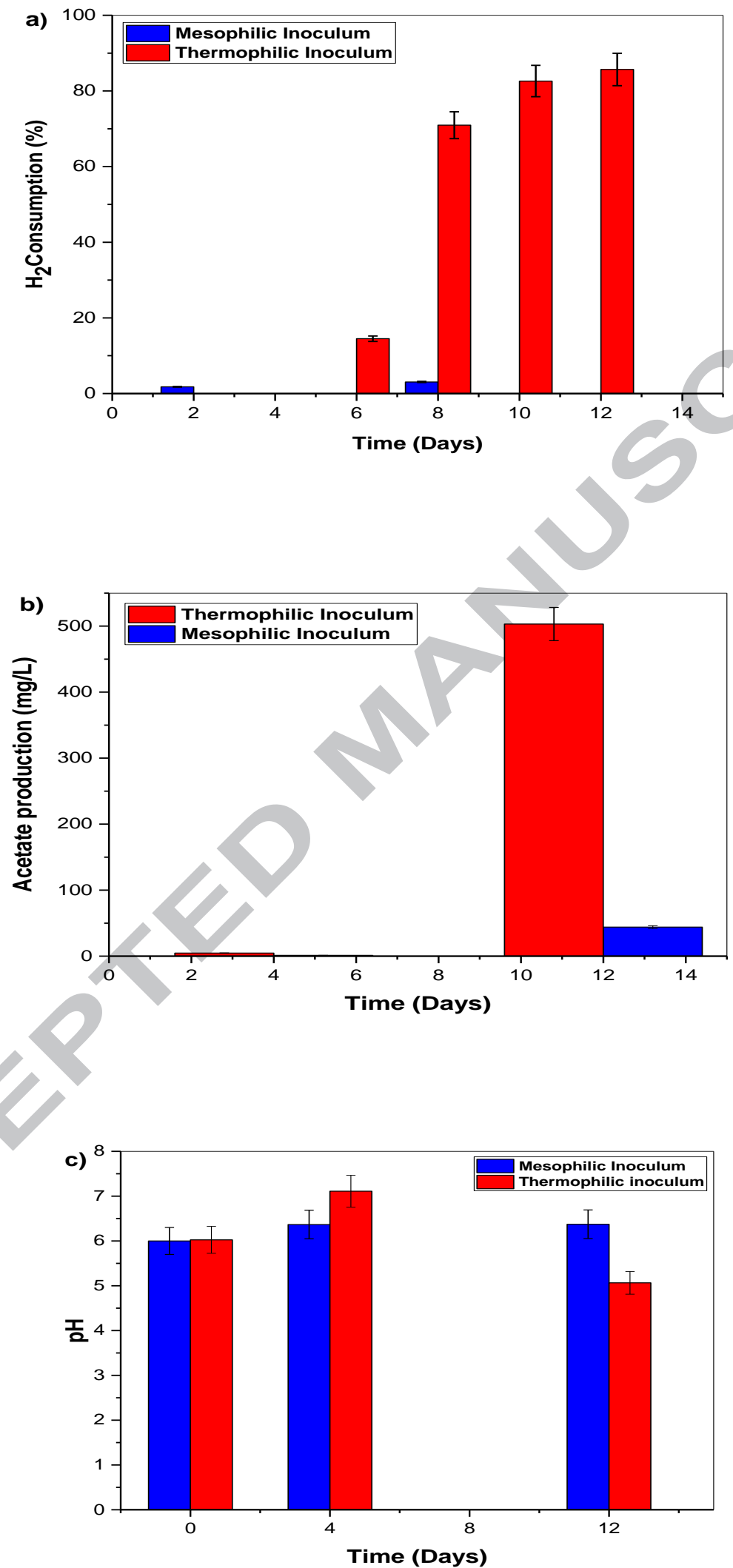

Fig.1 


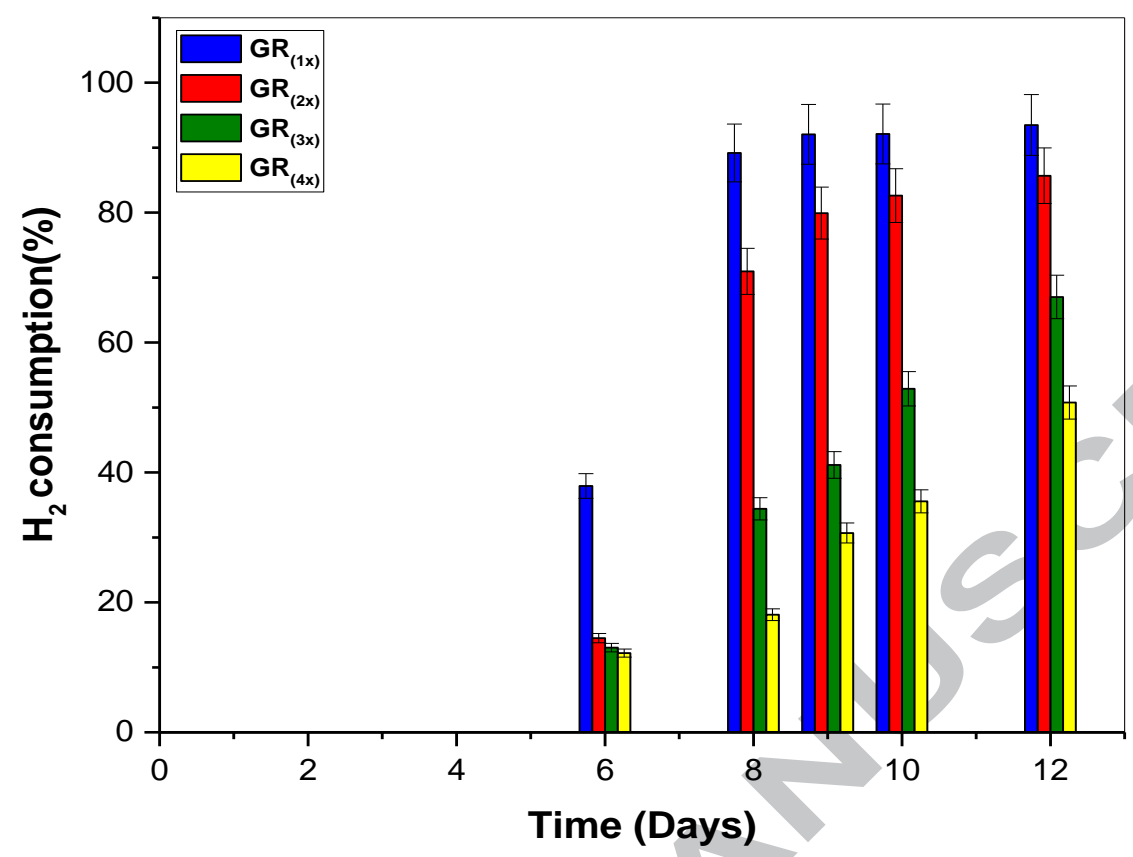

Fig. 2 

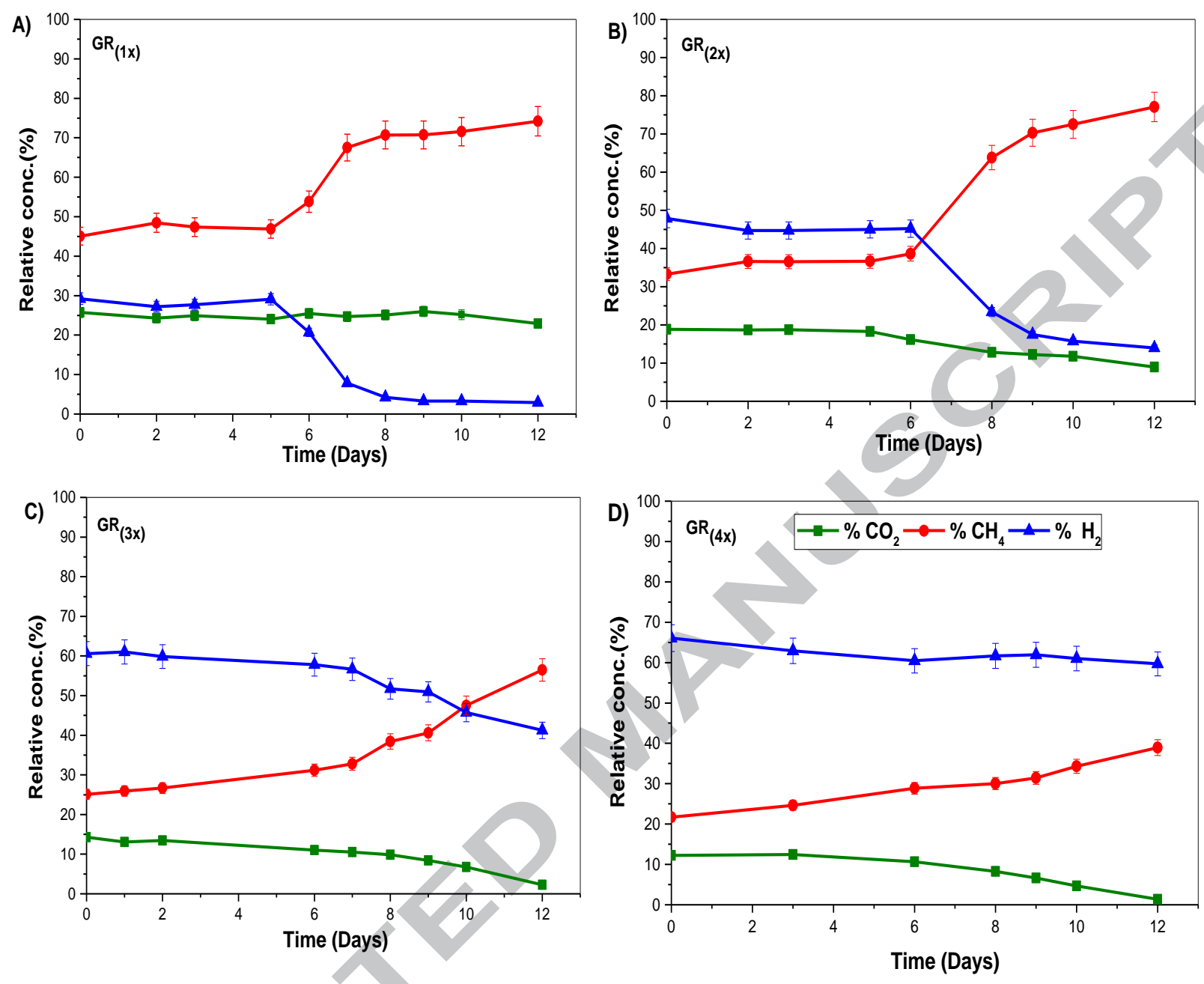

Fig. 3 


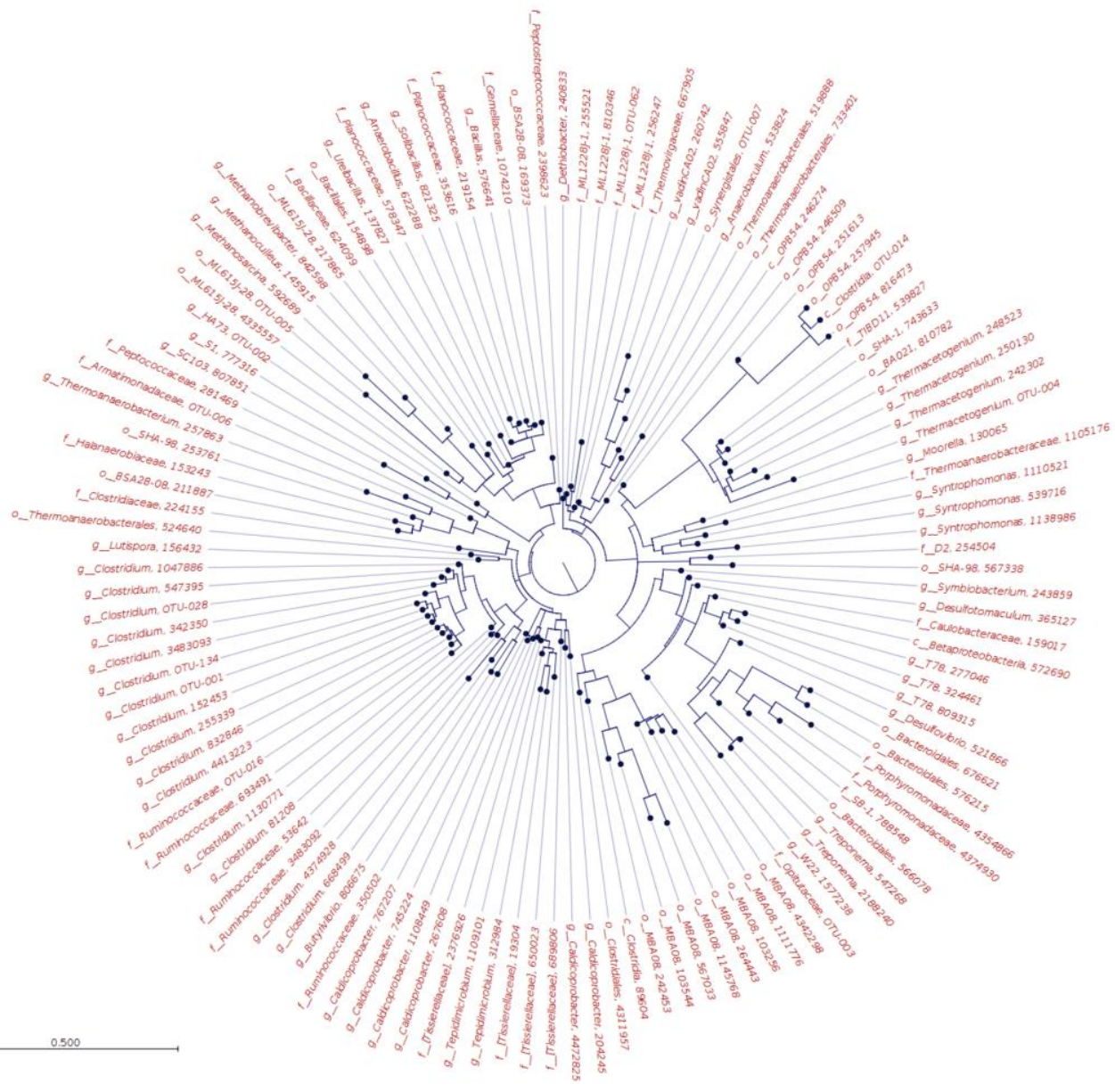

Fig. 4 


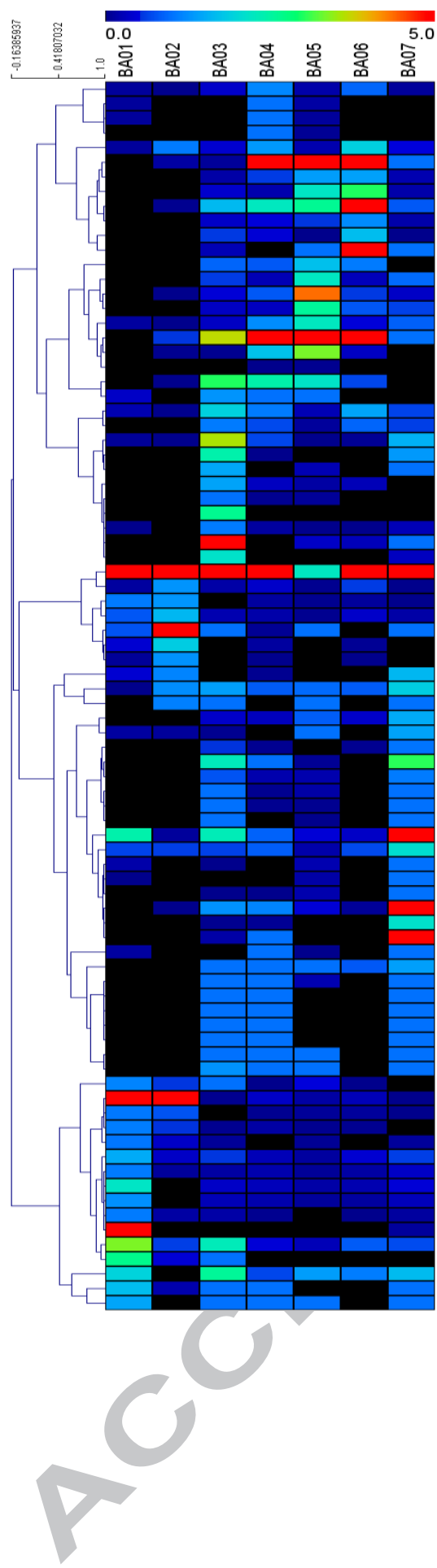

Natranaerobiales sp. 32

OP9 sp. 59
OP9 sp. 66

Treponema sp. 68

Thermoanaerobacterium sp. 11

Clostridiales sp. 15

Planococcaceae sp. 19

Ureibacillus thermosphaericus 27

Tepidanaerobacter syntrophicus 37

Methanomarcina thermophila 1
Tepidanaerobacter syntrophicus 28

Clostridiales sp. 26

Clostridium sp. 29.

Moorella sp. 4 .

Aeribacillus pallidus 18

Anaerolinaceae sp. 49

Clostridium $\mathrm{sp} \mathrm{g}^{2}$

Synergistaceae sp. 6

Clostridium sp. 14

[Clostridium] caenicola 21

[Tissierellaceae] sp. 55

SB-1 sp. 53

Clostridium sp. 62

Caldicoprobacter sp. 65

Clostridium sp. 77

MBA08 sp 1.77

Clostridales sp. 17

Anaerobacillus macyae

Syntrophomonas bryantii 50

Treponema sp. 52

Clostridia sp. 5

Opitutaceae sp. 76 . 39

Symbiobacterium
Clostridium sp. 46

Clostridia $\mathrm{sp}_{36} 46$.

Acetomicrobium faecale 22

Clostridium sp. 38

Bacteroidales sp. 60

Anaerolinaceae $\mathrm{sp}_{\text {. }} 61$

Clostridia sp. 7

Clostridia sp. 23

Anermovirgaceae sp. 54

Acetoanaerobium noterae 58

Clostridia sp. 10

Clostridia sp. 63
[Clostridium] caenicola 75

[Clostridium] caenicola 75
Synergistaceae sp. 56
Clostridiat sp. 41

[Cloacamonaceae] $\mathrm{sp}_{\text {. }} 73$

Lysinibachlus contaminans 78

Anaerolinaceae $\mathrm{sp}$
Solibacillus silvestris 80

Clostridia sp. 82

Basteriadales 30.16

[Tissierellaceael sp. 31
Porphyromonadaceae sp. 35

Clostria sp. 44

Thermoanaerobacteraceae sp. 42

Natranaerobiales sp. 43

Natranaerobiales s. 47

Halanaerobiaceae sp. 45
Syntrophaceticus schinkii 51

Anaerobaculum sp. 12

Thermacetog

Sinibacillus soli 67

Fig. 5 
Table 1

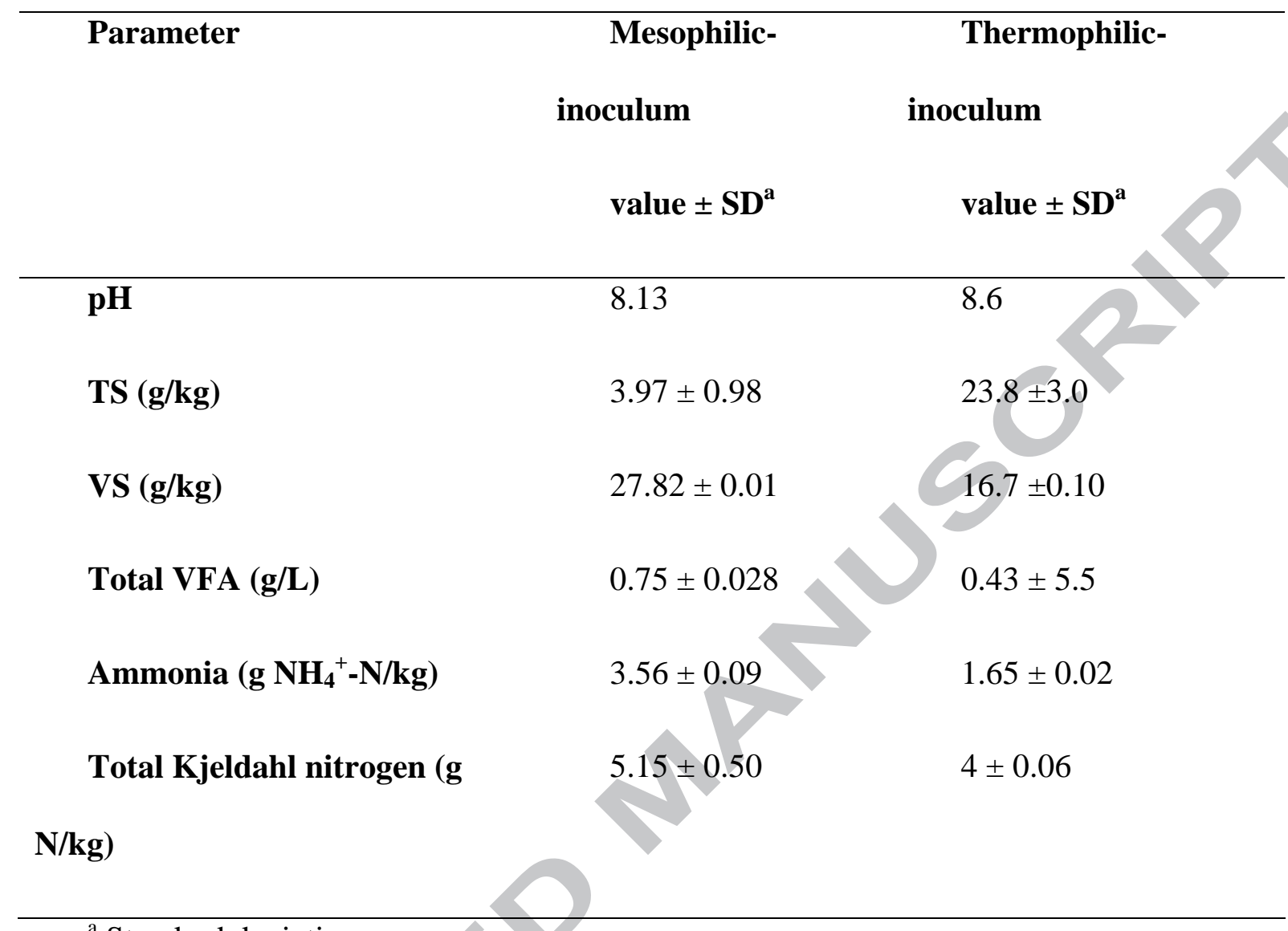

${ }^{\mathrm{a}}$ Standard deviation 


\section{Concentration}

\begin{tabular}{|c|c|c|c|c|c|c|c|c|c|c|c|}
\hline & \multicolumn{5}{|c|}{$\operatorname{mg}-\mathrm{COD}_{\mathbf{i}} / \mathbf{L}^{*}$} & \multicolumn{6}{|c|}{$\operatorname{mg}-\mathrm{COD}_{\mathrm{f}} / \mathrm{L}^{*}$} \\
\hline & & $\overline{G R}$ & & & GR & & $\overline{G R}$ & $\overline{\mathbf{G}}$ & $\bar{G}$ & $\bar{G}$ & $\bar{G}$ \\
\hline & $(\mathbf{1 x})$ & & $\mathbf{R}_{(2 \mathbf{x})}$ & $(3 \mathbf{x})$ & & $(4 \mathrm{x})$ & & $\mathbf{R}_{(\mathbf{1 x})}$ & $\mathbf{R}_{(2 \mathbf{x})}$ & $\mathbf{R}_{(3 \mathbf{x})}$ & $\mathbf{R}_{(4 \mathbf{x})}$ \\
\hline \multirow[t]{2}{*}{ Ethanol } & & 0.7 & & & 0.8 & & 0.6 & 1. & 5. & 3. & 1. \\
\hline & 6 & & 72 & 0 & & 5 & & 69 & 32 & 24 & 66 \\
\hline \multirow[t]{2}{*}{ Propanol } & & 12. & & & 12. & & 10. & 2. & & 1. & 2. \\
\hline & 74 & & .76 & 58 & & 20 & & & 9 & 70 & 21 \\
\hline \multirow[t]{2}{*}{ Butanol } & & 1.1 & & & 1.3 & & 1.3 & & 0. & - & - \\
\hline & 5 & & 18 & 0 & & 9 & & & 81 & & \\
\hline \multirow[t]{2}{*}{ 1-Hexanol } & & 0.8 & & & 0.5 & & 0.7 & 0. & 0. & 0. & - \\
\hline & 3 & & 98 & 7 & & 9 & & 00 & 19 & 15 & \\
\hline \multirow[t]{2}{*}{ Acetate } & & 17. & & & 17. & & 18. & 19 & 56 & 39 & 42 \\
\hline & 74 & & & & & 27 & & 1.50 & 1.34 & 1.37 & 3.27 \\
\hline \multirow[t]{2}{*}{ Butyrate } & & & & & 2.5 & & 2.5 & 3. & 3. & 2. & 3. \\
\hline & 4 & & 66 & 4 & & 5 & & 51 & 43 & 00 & 40 \\
\hline \multirow{4}{*}{$\begin{array}{l}\text { Valerate } \\
\text { Propionate }\end{array}$} & & & . & & - & & - & 0. & 0. & - & - \\
\hline & & & & & & & & 31 & 21 & & \\
\hline & & 6.2 & & & 6.1 & & 6.3 & 5. & 9. & 4. & 4. \\
\hline & 9 & & 35 & 9 & & 1 & & 62 & 90 & 20 & 98 \\
\hline \multirow{2}{*}{$\begin{array}{l}\text { Iso- } \\
\text { Butyrate }\end{array}$} & & 3.1 & & & 3.2 & & 3.1 & 1. & 3. & 1. & 1. \\
\hline & 4 & & 00 & 2 & & 2 & & 65 & 81 & 63 & 85 \\
\hline \multirow{2}{*}{$\begin{array}{c}1- \\
\text { Hexanoate }\end{array}$} & & 0.6 & & & 0.6 & & 0.6 & 0. & 0. & 0. & 0. \\
\hline & 6 & & 55 & 7 & & 3 & & 23 & 26 & 33 & 00 \\
\hline \multirow{2}{*}{$\begin{array}{c}\text { Iso- } \\
\text { Valerate }\end{array}$} & & 6.8 & & & 6.8 & & 7.0 & 5. & 8. & 4. & 6. \\
\hline & 7 & & 04 & 5 & & 0 & & 68 & 00 & 32 & 53 \\
\hline \multirow{2}{*}{$\begin{array}{l}\text { Iso- } \\
\text { Amylalcohol }\end{array}$} & & 0.1 & . & & 0.3 & & - & - & - & - & - \\
\hline & 4 & & & 7 & & & & & & & \\
\hline
\end{tabular}




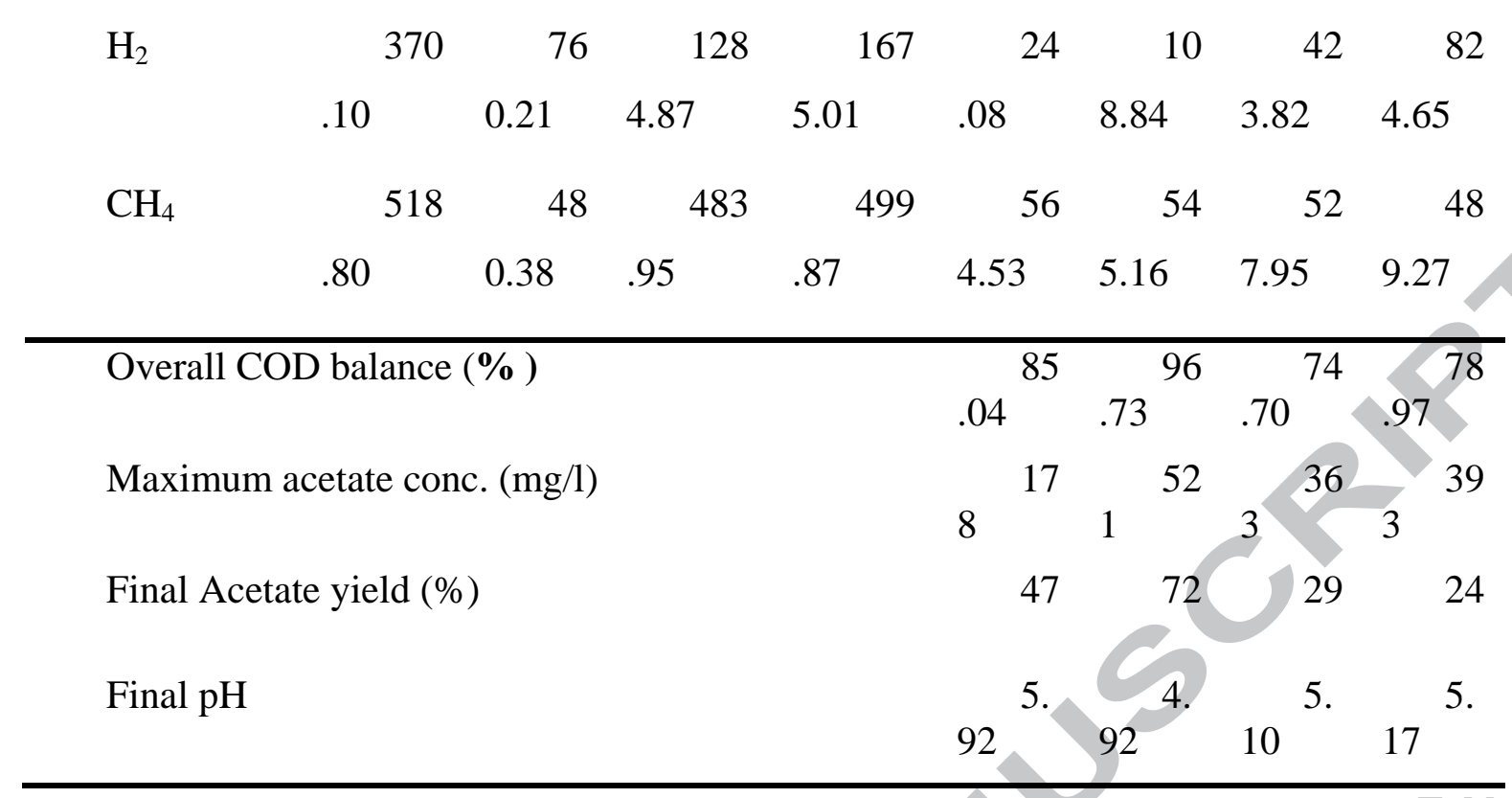

Table 2

* $\mathrm{COD}_{\mathrm{f}}$ : final COD, $\mathrm{COD}_{\mathrm{i}}$ : initial COD 


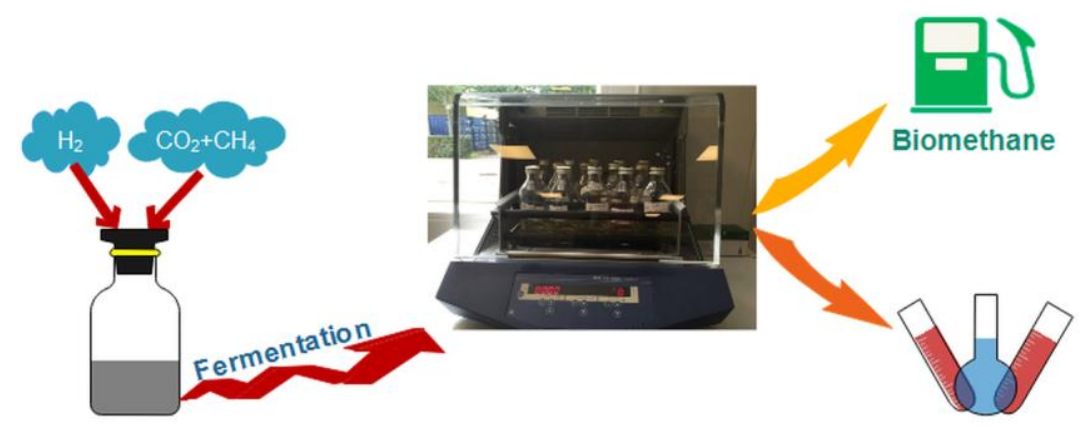

Chemicals 


\section{Highlights}

- Anaerobic mixed culture for efficient biogas upgrading and bioproduction.

- Biological conversion of $\mathrm{CO}_{2}$ and $\mathrm{H}_{2}$ into acetate through acidogenesis.

- Biogas upgrading up to $77 \% \mathrm{CH}_{4}$ was achieved under thermophilic conditions.

- Acetate yield of $72 \%$ was observed for $2 \mathrm{H}_{2}: 1 \mathrm{CO}_{2}$ gas ratio.

- Thermophilic acetogen, Moorella sp. 4, was responsible of acetate production. 